\title{
Aspiration and Readiness of Filipino Senior High School Students in Pursuing College Degree
}

\author{
Nonet A. Cuy*, Edwin M. Salinas \\ College of Arts and Sciences, University of Perpetual Help System Laguna, Biñan, Philippines \\ Email: ${ }^{*}$ ette_cuy@yahoo.com
}

How to cite this paper: Cuy, N.A. and Salinas, E.M. (2019) Aspiration and Readiness of Filipino Senior High School Students in Pursuing College Degree. Open Journal of Social Sciences, 7, 143-152. https://doi.org/10.4236/jss.2019.75012

Received: January 30, 2019

Accepted: May 17, 2019

Published: May 20, 2019

Copyright $\odot 2019$ by author(s) and Scientific Research Publishing Inc. This work is licensed under the Creative Commons Attribution International License (CC BY 4.0).

http://creativecommons.org/licenses/by/4.0/

\section{(c) (i) Open Access}

\begin{abstract}
This study aimed at determining the senior high school students' level of aspiration and level of readiness in pursuing college degree. It probed into whether there is a difference in the level of aspiration and level of readiness in pursuing college degree when grouped according to age, gender, average monthly family income and academic track. It also looked into the relationship between the respondents' level of aspiration and their level of readiness in pursuing college degree. This descriptive-correlational study involved 198 senior high school students of the University of Perpetual Help System Laguna, Binan Campus. Findings showed that majority of the respondents were young adult, female, with an average monthly family income of less than 30 thousand and belonged to STEM. The respondents showed very high level of aspiration and high level of readiness in pursuing college degree. Further, the female respondents who belonged to HUMSS had higher level of aspiration than the male respondents and those who belonged to HUMSS had higher level of readiness than those who belonged to aforesaid academic track. The respondents' aspiration was a strong predictor of their readiness in pursuing college degree.
\end{abstract}

\section{Keywords}

Aspiration, Readiness, College Degree, Senior High School

\section{Introduction}

College education and obtaining a college degree is a genuine desire of every student for it can be a passport for their future and life success. Most students seek college degree in order to have better career opportunities. Graduating se- 
nior high school students are confronted with deciding whether to pursue their college education or enter the workforce. The shift from high school to college is an adjustment that every student has to cope in their pursuit for college education. College provides a pathway for students to explore their interest, their socio-cultural experiences, and to build more promising career [1].

In recent years, individual's aspirations have received increased attention and their consequences for future-oriented behavior. Many students from different background are likely to develop high aspiration that is not related to their school performance [2] [3] [4] [5] [6]. Aspirations are sometimes expressed as desires or hopes and relatively stable beliefs [7]. It summarizes a subset of an individual's beliefs, preferences, and capacities relevant to one's future [8] [9] [10].

Khattab's study relates to the preset study, in the sense that examines how the aspirations, expectations and school achievement influence students' future educational behaviour [10]. The study shows that the higher the aspirations or expectations of the students, the higher their school achievement. Likewise, the study found out that the very significant predictor of future educational behavior among students is the combination of aspirations, expectation and school achievement.

Research shows that the economic payoff for having a college degree versus high school diploma is higher than ever [11]. Despite high increases in college enrolment for the past fifteen years, completion rates are still low [12]. Many students who are not ready for college-level courses are those students who are qualified and successfully enrolled in college. They struggle academically and personally and eventually drop out [13]. Some of them lack either the attitudes or capabilities vital to succeed and navigate college [14]. College readiness calls for a student to have a necessary mindset and disposition to succeed in college.

There have been various researches in determining college readiness. Nagaoka et al. (2013), posited that in addition to academic knowledge, a variety of non-cognitive factors (set of behaviors, skills, attitudes, and strategies) are crucial to students' success in college education [15]. College readiness is importance to degree completion [16]. Being well prepared academically for college increases a student's probability of finishing a college degree. It decreases gaps in tenacity and degree completion among racial and family income groups.

In order to ensure students' college readiness, Conley [17] [18] created four-part paradigm of college readiness: 1) cognitive strategies which are the forms of academic behavior leading to the enhancement of skills and capabilities essential for college work; 2) content knowledge pertains to the academic disciplines understanding that comprises English, Mathematics and Sciences; 3) academic behavior which requires the students to take their own responsibility for learning; and 4) contextual skills which include an understanding of choosing a college and how its operates as a system and a culture and financial aid programs.

Readiness in college necessitates an understanding of what it means to be "college ready". Earlier reviews of research on readiness in college focused indi- 
vidual-level indicators of whether a student is on track to be college ready. College readiness refers to academic and practical knowledge required to be successful in college education [19]. It is the level of students' preparedness without remediation that they need in order to succeed in college [13] [18] [20]. Mueller \& Gozali-Lee (2013) stated the factors contributing to lack of readiness in college and career: academic readiness and preparedness, expected behavior and attitudes, and college and career knowledge [21].

Reference [22] stated that there must be well-defined indicators of college readiness and performance criterions to turn college aspirations in to college attainment. These criterions must be established at the performance level of senior high school students to have a greater possibility of acquiring access to college education. Considering these barriers, the present study aimed at determining the aspirations and readiness of senior high school students in pursuing college degree at the University of Perpetual Help System Laguna. Specifically, it looked into the respondents' profile in terms of age, gender, average monthly family income and academic track, the respondents' level of aspiration and level of readiness in pursuing college degree. Likewise it also determined how does the respondents' level of aspirations and level of readiness in pursuing college degree differ when grouped according to profile as well as how does the respondents' level of aspirations relate to their level of readiness in pursuing college degree.

This study was anchored on college choice theory which focused on elements associated to student's decisions to pursue college education such as college aspirations, as a college choice process early phase [23]. It is described as the process that students experienced in transitioning from high school to college.

\section{Methods}

The present study was conducted at the University of Perpetual Help System Laguna, City of Binan, Laguna, Philippines. The researchers employed descriptive-correlational design and random sampling technique in choosing the target respondents of one hundred ninety eight (198) senior high school students. The researchers used Slovin's formula in determining the sample size. The study utilized a survey questionnaire with a Cronbach's Alpha of 0.857 for level of aspiration and 0.871 for level of readiness of the respondents.

The researchers asked permission from the Director of Senior High School Department before the actual gathering of data for ethical consideration. Upon the approval of the request, the researchers talked to the target respondents and discussed their purpose. The researchers personally administered and retrieved the survey questionnaires. After which, the data were tallied and tabulated for statistical analysis using SPSS version 22.

In answering the stated problems, appropriate statistical tools were utilized, such as frequency and percentages to determine the respondents' profile; weighted mean for the level of aspirations and level of readiness of the respondents; tests of difference such as Mann-Whitney and Kruskal-Wallis test to de- 
termine if the level of aspirations and level of readiness of the respondents differ when grouped according to profile; and Pearson product moment correlation ( $\mathrm{r}$ ) for the relationship problem.

\section{Results and Discussion}

As shown in Table 1, out of one hundred ninety-eight (198) respondents, one hundred thirty two (132) or 66.67 percent aged 18 and above and sixty six (66) or 33.33 percent aged 16 - 17. More than half of the respondents were female with a frequency of 121 and only seventy-seven were male. Majority of them had an average monthly family income of 20 to 30 thousand, sixty-one (61) or 34.85 percent had an average monthly family income of below 20 thousand and lastly forty (40) or 12.12 percent had an average monthly family income of more than 3o thousand. Nearly half of the respondents belonged to STEM; forty (40) of them belonged to AB; thirty-six (36) belonged to TVL; twenty-five (25) belonged to HUMSS and only eleven (11) of the respondents belonged to GAS. The results imply that majority of the respondents were young adults, female, with an average monthly family income of 30,000 or less and under the academic track of STEM.

As reflected in Table 2, the respondents had very high level of aspiration in pursuing college degree as evidenced by an overall weighted mean of 3.65. The respondents strongly agreed that they will do their best to achieve their goals; to do well in school to fulfill their dreams, and to finish college regardless of obstacles. Likewise the respondents were very positive and confident of their academic abilities and skills needed in college and wanted to explore new ideas. As a whole the respondents had clear aspiration of what they really wanted in pursuing college education.

Table 1. The respondents' profile.

\begin{tabular}{cccc}
\hline & Profile & Frequency & Percentage \\
\hline Age & $16-17$ & 66 & 33.33 \\
& 18 and above & 132 & 66.67 \\
Gender & Male & 77 & 38.89 \\
& Female & 121 & 61.11 \\
Average & Above 30,000 & 40 & 12.12 \\
monthly & 20,000 - 30,000 & 97 & 53.03 \\
family income & Below 20,000 & 61 & 34.85 \\
Academic & STEM & 86 & 43.43 \\
track & ABM & 40 & 20.20 \\
& HUMSS & 25 & 12.63 \\
& TVL & 36 & 18.18 \\
& GAS & 11 & 5.56 \\
\hline
\end{tabular}


Table 2. The respondents' level of aspiration in pursuing college degree.

\begin{tabular}{lccc}
\hline \multicolumn{1}{c}{\begin{tabular}{l}
\multicolumn{1}{c}{ Indicators } \\
I aspire to...
\end{tabular}} & $\begin{array}{c}\text { Weighted } \\
\text { Mean }\end{array}$ & $\begin{array}{c}\text { Verbal } \\
\text { Interpretation }\end{array}$ & Rank \\
\hline $\begin{array}{l}\text { 1) do well in school to fulfill my dream. } \\
\begin{array}{l}\text { 2) enjoy my college years before assuming } \\
\text { adult responsibilities. }\end{array}\end{array}$ & 3.81 & Very High (SA) & 2 \\
$\begin{array}{l}\text { 3) achieve a high general weighted average } \\
\text { (GWA). }\end{array}$ & 3.53 & Very High (SA) & 11 \\
$\begin{array}{l}\text { 4) decide on what career I want to pursue. } \\
\text { 5) explore new ideas. }\end{array}$ & 3.61 & Very High (SA) & 8 \\
$\begin{array}{l}\text { 6) acquire a well-rounded general education. } \\
\text { 7) obtain a skills I need to pursue my }\end{array}$ & 3.69 & Very High (SA) & 6 \\
chosen career. & 3.52 & Very High (SA) & 12 \\
$\begin{array}{l}\text { 8) discover what kind of person I really } \\
\text { want to be. }\end{array}$ & 3.70 & Very High (SA) & 5 \\
9) consistently do my school work well. & 3.64 & Very High (SA) & 7 \\
$\begin{array}{l}\text { 10) do my best to achieve my goals. } \\
\text { 11) finish college regardless of obstacles. }\end{array}$ & 3.55 & Very High (SA) & 10 \\
$\begin{array}{l}\text { 12) develop a personal code of values and ethics. } \\
\text { 13) be confident of my academic abilities. }\end{array}$ & 3.85 & Very High (SA) & 1 \\
& 3.78 & Very High (SA) & 3 \\
\hline
\end{tabular}

$3.51-4.00 \mathrm{VH}, 2.51-3.50 \mathrm{H}, 1.51-2.50 \mathrm{~L}, 1.00-1.50 \mathrm{VL}$.

Reference [24] stated that if a student has a vision of what he wants for his future and the education he is receiving moves him toward that vision, he is strongly motivated to give his best effort and engage more fully in the learning process.

As gleaned in Table 3, the respondents' level or readiness in pursuing college degree ranged from high to very high with an obtained weighted means of 3.19 to 3.66. The respondents strongly agreed that they had strong desire to be successful in college $(x=3.66)$; had an idea of what they wanted to do with their career $(\mathrm{x}=3.63)$ and knew the importance of not giving up and sticking through difficult tasks $(x=3.51)$. In addition, the respondents agreed that they set clear achievement goals, self-disciplined, self-motivated and optimistic of their future; understood their academic strengths and had clear college goals. This implies that the respondents were ready to face the challenges of college education.

However, [21] said that many students are not ready for college-level courses based on national and local data. Almost 54 percent of high school graduates in Minnesota public colleges and universities and 53 percent from Saint Paul school district needed to take remedial courses [25].

As seen in Table 4, no difference was noted in the respondents' level of aspiration in pursuing college degree when grouped according to age and average monthly family income. The computed probability values of 0.217 and 0.700 respectively were bigger than the significance level of 0.05 . The results imply that 
Table 3. The respondents' level of readiness in pursuing college degree.

\begin{tabular}{|c|c|c|c|}
\hline $\begin{array}{c}\text { Indicators } \\
\text { In pursuing college degree... }\end{array}$ & $\begin{array}{l}\text { Weighted } \\
\text { Mean }\end{array}$ & $\begin{array}{c}\text { Verbal } \\
\text { Interpretation }\end{array}$ & Rank \\
\hline 1) I have clear college goals. & 3.38 & High (A) & 10 \\
\hline 2) I can handle change well. & 3.27 & High (A) & 13 \\
\hline $\begin{array}{l}\text { 3) I am quick to get things done and } \\
\text { self-motivated. }\end{array}$ & 3.39 & $\operatorname{High}(\mathrm{A})$ & 9 \\
\hline $\begin{array}{l}\text { 4) I take care of myself and can handle } \\
\text { uncertainty. }\end{array}$ & 3.37 & High (A) & 11 \\
\hline 5) I can manage my time well. & 3.19 & $\operatorname{High}(\mathrm{A})$ & 15 \\
\hline $\begin{array}{l}\text { 6) I have done some serious thinking about } \\
\text { career options. }\end{array}$ & 3.26 & High (A) & 14 \\
\hline $\begin{array}{l}\text { 7) I have a distinct desire to be successful } \\
\text { in college. }\end{array}$ & 3.66 & Very High (SA) & 1 \\
\hline $\begin{array}{l}\text { 8) I am self-disciplined (if something needs to } \\
\text { be done, I do it in a timely manner). }\end{array}$ & 3.44 & $\operatorname{High}(\mathrm{A})$ & 5.5 \\
\hline $\begin{array}{l}\text { 9) I take responsibility for my decisions for } \\
\text { I am a good decision maker. }\end{array}$ & 3.31 & High (A) & 12 \\
\hline 10) I am optimistic about my future. & 3.44 & High (A) & 5.5 \\
\hline 11) I set clear achievement goals for myself. & 3.45 & $\operatorname{High}(\mathrm{A})$ & 4 \\
\hline $\begin{array}{l}\text { 12) I can organize my time and things } \\
\text { I need to do. }\end{array}$ & 3.41 & $\operatorname{High}(\mathrm{A})$ & 8 \\
\hline 13) I understand my academic strengths. & 3.42 & $\operatorname{High}(\mathrm{A})$ & 7 \\
\hline $\begin{array}{l}\text { 14) I know the importance of not giving up } \\
\text { and sticking through difficult tasks. }\end{array}$ & 3.51 & Very High (SA) & 3 \\
\hline $\begin{array}{l}\text { 15) I have an idea of what I want to do } \\
\text { with my career. }\end{array}$ & 3.63 & Very High (SA) & 2 \\
\hline Average & 3.41 & High (A) & \\
\hline
\end{tabular}

$3.51-4.00 \mathrm{VH}, 2.51-3.50 \mathrm{H}, 1.51-2.50 \mathrm{~L}, 1.00-1.50 \mathrm{VL}$.

the respondents' level of aspiration in pursuing college degree were the same regardless of their age and average monthly family income.

On the other hand, a difference was noted in the respondents' level of aspiration in pursuing college degree when grouped according to gender and academic track. The computed probability values of 0.10 and 0.024 were less than the significance level of 0.05 . The results imply that female respondents and belonged to HUMSS had higher level of aspiration compared with their male counterpart and those belonged to other aforementioned academic track.

Further, [26] posited that students' academic aspirations were influenced by family, school and personal factors which include social support, academic self-concept and school environment perceptions.

As reflected in Table 5, there was no significant difference in the respondents' level of readiness in pursuing college degree when grouped according to age, gender and average monthly family income. The computed probability values 
Table 4. Difference in the respondents' level of aspiration in pursuing college degree when grouped according to profile.

\begin{tabular}{|c|c|c|c|c|}
\hline \multicolumn{2}{|c|}{ Profile } & \multirow{2}{*}{$\begin{array}{c}\text { Mean } \\
3.70\end{array}$} & \multirow[t]{2}{*}{ Test statistics } & \multirow[t]{2}{*}{ Interpretation } \\
\hline \multirow{5}{*}{ Age } & $16-17$ & & & \\
\hline & \multirow{4}{*}{18 and above } & & (Mann-Whitney test) & \multirow{4}{*}{ Not Significant } \\
\hline & & \multirow{3}{*}{3.62} & $\mathrm{U}=3890.50$ & \\
\hline & & & $\mathrm{z}=-1.234$ & \\
\hline & & & $\mathrm{p}=0.217$ & \\
\hline \multirow{3}{*}{ Gender } & Male & 3.59 & \multirow{3}{*}{$\begin{array}{c}U=3657.00 \\
z=-2.568 \\
p=0.010\end{array}$} & \multirow{3}{*}{ Significant } \\
\hline & & & & \\
\hline & Female & 3.69 & & \\
\hline \multirow{4}{*}{$\begin{array}{l}\text { Average monthly } \\
\text { family income }\end{array}$} & Above 30,000 & 3.63 & \multirow{3}{*}{ 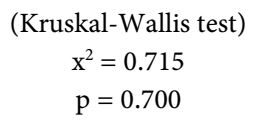 } & \multirow{3}{*}{ Not Significant } \\
\hline & $20,000-30,000$ & 3.67 & & \\
\hline & Below 20,000 & 3.62 & & \\
\hline & STEM & 3.64 & \multirow{5}{*}{$\begin{aligned} \mathrm{x}^{2} & =11.214 \\
\mathrm{p} & =0.024\end{aligned}$} & \multirow{5}{*}{ Significant } \\
\hline \multirow{4}{*}{ Academic track } & $\mathrm{ABM}$ & 3.69 & & \\
\hline & HUMSS & 3.78 & & \\
\hline & TVL & 3.57 & & \\
\hline & \multirow[t]{2}{*}{ GAS } & 3.48 & & \\
\hline & & ificant & & \\
\hline
\end{tabular}

Table 5. Difference in the respondents' level of readiness in pursuing college degree when grouped according to profile.

\begin{tabular}{|c|c|c|c|c|}
\hline \multicolumn{2}{|c|}{ Profile } & \multirow{2}{*}{$\begin{array}{c}\text { Mean } \\
3.70\end{array}$} & \multirow{2}{*}{$\begin{array}{c}\text { Test statistics } \\
\text { (Mann-Whitney test) }\end{array}$} & \multirow[t]{2}{*}{ Interpretation } \\
\hline \multirow{4}{*}{ Age } & $16-17$ & & & \\
\hline & & & $\mathrm{U}=4101.50$ & \multirow{3}{*}{ Not Significant } \\
\hline & 18 and above & 3.62 & $z=-0.671$ & \\
\hline & & & $\mathrm{p}=0.502$ & \\
\hline \multirow{3}{*}{ Gender } & Male & 3.59 & $\mathrm{U}=4431.00$ & \multirow{3}{*}{ Not Significant } \\
\hline & & & $\mathrm{z}=-0.580$ & \\
\hline & Female & 3.69 & $\mathrm{p}=0.562$ & \\
\hline \multirow{3}{*}{$\begin{array}{l}\text { Average } \\
\text { monthly } \\
\text { family } \\
\text { income }\end{array}$} & Above 30,000 & 3.63 & (Kruskal-Wallis test) & \multirow{3}{*}{ Not Significant } \\
\hline & $20,000-30,000$ & 3.67 & $\mathrm{x}^{2}=0.444$ & \\
\hline & Below 20,000 & 3.62 & $\mathrm{p}=0.801$ & \\
\hline \multirow{7}{*}{$\begin{array}{c}\text { Academic } \\
\text { track }\end{array}$} & STEM & 3.64 & \multirow{7}{*}{$\begin{aligned} x^{2} & =10.207 \\
p & =0.037\end{aligned}$} & \multirow{7}{*}{ Significant } \\
\hline & $\mathrm{ABM}$ & 3.69 & & \\
\hline & HUMSS & 3.78 & & \\
\hline & 1101 1910 & 0.10 & & \\
\hline & TVL & 3.57 & & \\
\hline & \multirow[t]{2}{*}{ GAS } & 3.48 & & \\
\hline & & Significant@0.05 & & \\
\hline
\end{tabular}

$0.502,0.562$, and 0.801 respectively were all bigger than the significance level of 0.05 . This means that the respondents had the same level of readiness in pursuing college degree regardless of their age, gender, and average monthly family 
income.

However, there was a significant difference in the respondents' level of readiness in pursuing college degree when grouped according to academic track. The computed probability value of 0.037 was smaller than the significance level of 0.05. This implies that based on their academic track, the respondents had different perception of their level of readiness.

As shown in Table 6, a significant correlation existed between the respondents' level of aspiration and their level of readiness in pursuing college degree. The computed probability value of 0.000 was smaller than the significance level of 0.01 . This implies that if the respondents had higher level of aspirations, they also had higher level of readiness in pursuing college education. The result was similar to the study made by [27]. They found out that the skills and strategies related to college readiness predict aspirations for grade 12 students.

Table 6. Relationship between the respondents' level of aspiration and their level of readiness in pursuing college degree.

\begin{tabular}{llcc}
\hline \multicolumn{1}{c}{ Indicator } & Pearson $\mathrm{r}$ & $\mathrm{p}$-value & Interpretation \\
\hline $\begin{array}{l}\text { Respondents' Level of } \\
\begin{array}{l}\text { Aspiration and their Level } \\
\text { of Readiness in Pursuing } \\
\text { College Degree }\end{array}\end{array}$ & 0.304 & 0.000 & Significant \\
& & & \\
& Significant @ 0.01 & \\
\hline
\end{tabular}

\section{Conclusion}

Aspiration signifies a desire to achieve something. Every student wanted to achieve their goal for their future. To achieve that goal they must be ready for college education. Based on the results of the present investigation, it can be concluded that majority of the respondents were young adults, female, with an average monthly family income of 30,000 or less and under the academic track of STEM. The respondents had very high level of aspiration and high level of readiness in pursuing college degree. The respondents will do their very best and had strong desire to be successful to achieve their dream. The respondents had the perseverance and determination in pursuing college education. Moreover, the female respondents who belonged to HUMSS had higher level of aspiration than the male respondents and those who belonged to HUMSS had higher level of readiness than those who belonged to aforesaid academic track. Further, the respondents' aspiration was a strong predictor of their readiness in pursuing college degree.

\section{Future Directions}

To conceptualize the essence of the present investigation, the following recommendations are hereby endorsed: though the respondents had very high level of aspiration, parents and teacher should encourage the students to maintain their level of aspirations and should be reinforced by equipping them with the necessary 
knowledge and skills needed in college education. In addition, the senior high school students should built a strong academic foundation, strengthen their skills, develop critical thinking, establish effective time management and study habits, and learn how to communicate effectively through writing and speaking in order to be college ready. Further, considering the limitations of the present study, it is recommended that in the future studies data may be increased to get more accurate results. More variables like expectations and academic preparedness may also be studied.

\section{Conflicts of Interest}

The authors declare no conflicts of interest regarding the publication of this paper.

\section{References}

[1] Falcon, L. (2015) Breaking Down Barriers: First-Generation College Students and College Success. Innovation Showcase, 10.

http://www.league.org/innovation-showcase/breaking-down-barriers-first-generati on-college-students-and-college-success

[2] Goodman, A., Gregg, P. and Washbrook, E. (2011) Children's Educational Attainment and the Aspirations, Attitudes and Behaviors of Parents and Children through Childhood. Longitudinal and life Course Studies, 2, 1-18.

https://doi.org/10.14301/llcs.v2i1.147

[3] Carter-Wall, C. and Whitfield, G. (2012) The Role of Aspirations, Attitudes and Behavior in Closing the Educational Attainment Gap. Joseph Rowntree Foundation, York.

[4] Cummings, C., Laing, K., Law, J., McLaughlin, J., Papps, I., Todd, L. and Woolner, P. (2012) Can Changing Aspirations and Attitudes Impact on Educational Attainment. Joseph Rowntree Foundation, York.

[5] Gorard, S., See, B.H. and Davies, P. (2012) The Impact of Attitudes and Aspirations on Educational Attainment and Participation. http://www.jrf.org.uk/sites/files/jrf/education-young-people-parents-full.pdf

[6] St. Clair, R., Kintrea, K. and Houston, M. (2013) Silver Bullet or Red Herring? New Evidence on the Place of Aspirations in Education. Oxford Review of Education, 39, 719-738. https://doi.org/10.1080/03054985.2013.854201

[7] Elliot, W. III (2008) At-Risk Children's College Aspirations and Expectations: The Potential of College Savings Account. Center for Social Development Washington University, St. Loius.

[8] Bernard, T. and Taffesse, A.S. (2012) Measuring Aspirations: Discussion and Example from Ethiopia. Ethiopia Strategy Support Program II Working Paper 47.

[9] Bernard, T., Dercon, S. and Taffesse, A.S. (2011) Beyond Fatalism-An Empirical Exploration of Self-Efficacy and Aspirations Failure in Ethiopia. Working Paper CSAE WPS/2011-03. University of Oxford, Center for Studies on African Economics, Oxford.

[10] Khattab, N. (2015) Students' Aspirations, Expectations and School Achievement: What Really Matters? British Educational Research Journal, 41, 731-748. https://doi.org/10.1002/berj.3171

[11] Carnavale, A.P., Rose, S.J. and Cheah, B. (2011) The College Payoff: Education, 
Occupations, Lifetime Earnings. Georgetown University Center on Education and the Workforce, Washington DC.

[12] U.S. Department of Education, National Center for Education Statistics (2012) The Condition of Education 2011. NGES 2012-045, NCES, Washington DC.

[13] Conley, D.T. (2007) Redefining College Readiness. Volume 3, Educational Policy Improvement Center, Eugene.

[14] Jackson, C.K. (2009) A Stitch in Time: Evaluating the Effects of an AP Incentive Program on College Outcomes. Cornell University, Ithaca.

[15] Nagaoka, J., Farrington, C.A., Roderick, M., Allensworth, E., Keyes, T.S., Johnson, D.W. and Beechum, N.O. (2013) Readiness for College: The Role of Non-Cognitive Factors and Context. Voices in Urban Education, 38, 45-52.

[16] ACT (2013) Readiness Matters: The Impact of College Readiness on College Persistence and Degree Completion. http://www.act.org/research

[17] Conley, D.T. (2008) What Makes a Student College Ready? Expecting Excellence, 66.

http://www.ascd.org/publications/educational-leadership/oct08/vol66/num02/What -Makes-a-Student-College-Ready\%C2\%A2.aspx

[18] Conley, D.T. (2010) College and Career Ready. Jossey-Bass, San Francisco. https://doi.org/10.1002/9781118269411

[19] Pitre, C.C. and Pitre, P. (2009) Increasing Underrepresented High School Students' College Transitions and Achievements. NASSP Bulletin, 93, 96-110. https://doi.org/10.1177/0192636509340691

[20] Conley, D.T. (2005) College Knowledge. Jossey-Bass, San Francisco.

[21] Mueller, D. and Gozali-Lee, E. (2013) College and Career Readiness: A Review and Analysis Conducted for Generation Next. Wilder Research, St. Paul.

[22] Roderick, M., Nagaoka, J. and Coca, V. (2009) College Readiness for All: The Challenge for Urban High Schools. The Future of Children, 19, 185-210. https://doi.org/10.1353/foc.0.0024

[23] Trolian, T.L. (2016) Considering the Influence of High School Experiences on Students' College Aspirations. PhD Thesis, University of Iowa, Iowa.

[24] Conley, D.T. (2015) Student Aspirations: Key to Powerful Learning. http://www.pearsoned.com/student-aspirations-key-to-powerful-learning

[25] Minnesota State Colleges and Universities \& University of Minnesota (2011) Getting Prepared: A 2010 Report on Recent High School Graduates Who Took Developmental/Remedial Courses.

http://www.minnstate.edu/media/newsreleases/2011/pdf/1_getting_prepared.pdf

[26] Othman, N., Nordin, F., Mat Nor, N., Endot, Z., Azmi, A., Ismail, I. and Yaakob, A. (2013) Factors Influencing Students' Academic Aspirations in Higher Institution: A Conceptual Analysis. Procedia-Social and Behavioral Sciences, 90, 411-420. https://doi.org/10.1016/j.sbspro.2013.07.110

[27] Gilkey, E.M., Seburn, M. and Conley, D.T. (2012) College Aspirations and College Knowledge: Students' Preparation for Post-Secondary Aspirations. Inflexion. http://www.inflexion.org/college-aspirations-and-college-knowledge 